\title{
Spinoza and the possibilities for radical climate ethics
}

Dialogues in Human Geography 2017, Vol. 7(2) 156-160

(C) The Author(s) 2017

Reprints and permission:

sagepub.co.uk/journalsPermissions.nav DOI: $10.1177 / 2043820617720063$

journals.sagepub.com/home/dhg

(S)SAGE
Hasana Sharp

McGill University, Canada

\begin{abstract}
In this commentary, I endeavor to respond to what I identify as the core question of Ruddick's paper: How does the theoretical dethroning of humanity force us to reinvent ethics? I expand on Spinoza's profound contribution to the radical rethinking of the subject at the level of ontology. Although Ruddick invokes Spinoza, first and foremost, as a potential resource for ethics in light of climate disruption, I conclude that those resources offer only a glimmer of how to live differently. The work of reimagination at the level of metaphysics is flourishing, but we have yet to develop its implications for ethics and politics.
\end{abstract}

\section{Keywords}

anthropocentrism, ethics, ecology, Spinoza

So what if humans are not metaphysically exceptional, uniquely minded, or exclusive bearers of value? So what if bodies do not end at the skin and minds are not internal to individual human subjects? So what if ecological systems exhibit a kind of savoir faire, a clever power to recompose themselves and persevere in creative response to radical changes? What do these revolutionary perspectives in ontology, metaphysics, and epistemology imply as we confront myriad threats of ecological devastation? What does the insistence on the illegitimacy of human metaphysical privilege entail when human and nonhuman interests come into conflict? And how on earth can a 17 th-century rationalist like Benedict de Spinoza help us to approach these questions?

Susan Ruddick undertakes the ambitious effort to stage an encounter between neovitalism and environmental ethics. She urges those advocating a livelier apprehension of matter, organic, and inorganic networks of power to consider the elephant (crack- up) in the room. Once we see how profoundly connected we are at the level of ontology and need, what do we do? How do we reckon with the effects of centuries of imperialism on the part of some humans? How does the theoretical dethroning of humanity as a category force us to reinvent ethics?

While Ruddick (2017), in her paper 'Rethinking the subject, reimagining worlds', does not presume to answer these questions, she constructs a web of diverse thinkers, not usually in conversation with one another, to form 'a compass' for the 21 st century. Honored to be woven into this web, I nevertheless confess my humility before the articulation of a (if not the) fundamental challenge of our age.

\section{Corresponding author:}

Hasana Sharp, Associate Professor of Philosophy, McGill University, 855 Sherbrooke St. W., Montreal (QC) H3A 2T7, Canada.

Email: hasana.sharp@mcgill.ca 
Since I am a specialist of Spinoza's philosophy, I will confine myself to the task here of elaborating on his profound challenge to any concept of 'the subject' with particular attention to its implications for an anti-anthropocentric ethics. I will conclude with a consideration of the problem of antagonism among humans and nonhumans, which has become increasingly acute in light of climate disruption. Many revolutionary perspectives in ontology and metaphysics cite Spinoza as inspiration. Indeed, his philosophy offers a treasure trove of resources for an expanded and anti-anthropocentric understanding of the individual, mind, striving, interest, among other major concepts. In order to address the problem of ethical conflict, however, we must, as Ruddick does, think with rather than merely about Spinoza (cf. Macherey, 1992). With Spinoza, we might still hope for a better compass, but given the unprecedented character of what the future promises, the work of reimagining ethics has only just begun.

Ruddick finds in Spinoza's ethics at least three promising features: (i) human individuals are 'composite', meaning that they are multiple and complex, necessarily constituted by many diverse powers, many (even most!) of which we would call 'nonhuman'; (ii) 'subjects' ('things' or 'finite modes', in Spinoza's language) strive in such a way that they must expand, overflow, and connect to others; and (iii) it is possible to evaluate whether and how certain compositions are enabling or disabling, good or bad. Spinoza's ethics thus acknowledges and affirms the tremendous diversity of life, the extent to which nonhuman reality constitutes human existence, but without surrendering the possibility of normative evaluation. Even if what is good for each singular being is unique to that thing, it is objectively the case that some relations or beings really are good or bad, helpful or harmful. Moreover, the ethical reasoning sensitive to singularities that Spinoza undertakes is not confined to the unique needs of diverse human individuals, but also to what enhances the being of a couple, a commonwealth, a people, a crowd, and so on. Etienne Balibar declares that Spinoza's originality lies in his treatment of 'them ass' as his 'principal object of investigation, reflection, and historical analysis' (1989: 106). Nevertheless, Spinoza gives negligible attention to nonhuman powers, to how forms of human association are always necessarily comprised of nonhuman elements. Ruddick pushes Spinoza beyond Spinoza in pursuit of a posthumanist ethics that affirms both the value of biodiversity and the reality of radical antagonism. It will be my effort in what follows, as a Spinoza scholar, to clarify still further what Spinoza offers her laudable project.

Ruddick (and others) are absolutely correct to find in Spinoza's philosophy a profound challenge to our inherited conceptions of human subjectivity. Best known, of course, is Spinoza's rejection of dualism, according to which mind (thought) and body (extension) are fundamentally different things, obeying two distinct sets of laws, and differently valued (see Plumwood, 1993: Ch. 2). From the point of view of Cartesian dualism, extended matter conforms predictably and necessarily to a rigid order of cause and effect. Bodies are not self-organizing; they are governed by inertia and derive their power from outside them. Mind, in contrast, is infinite, unconstrained by the rules of efficient causality, and internally determined. Because mind is, in some respect (i.e. the faculty of the will), infinite and independent, it is of greater value than the finite and dependent body. Dualism, then, maintains a mutually exclusive binary, such that one member is of greater metaphysical and moral value. This is the well-known metaphysical underpinning of human exceptionalism. As René Descartes notes, animated by egalitarian impulses, things are minded or they are not (Descartes, 1988: 20). All humans are minded, and thus we are all equal to each other. Yet, among created beings, mind is an exclusive (and thus defining, essential) property of human beings, which makes us superior to all other earthlings.

The exclusiveness and absolute difference of mind from matter undergirds the dominant current of humanism in western thought. It is a metaphysical thesis with the moral implication that humans alone are moral ends and merit distinctive moral consideration. As Immanuel Kant puts it:

Through reason, man conceived himself (though only darkly) to be the true end of nature, and in this regard nothing living on earth can compete with him. The first time he said to the sheep, 'the pelt that you bear was 
given to you by nature not for yourself, but for me'; the first time he took that pelt and put it on himself (Gen $3: 21)$.. he saw within himself the privilege by virtue of which his nature surpassed that of all animals, which he no longer regarded as fellows in creation, but as subject to his will as means and tools for achieving his own chosen objectives. (Kant, 1970: 225)

Nonhumans can be instruments, ends to the means of others, but humans demand a totally distinct moral orientation. Humans, and humans alone, deserve to be respected as absolute values, ends in themselves.

As both Gilles Deleuze (1994) and Antonio Negri (1991) have perhaps done the most to show, Spinoza's philosophy yields rich possibilities for a flatter metaphysical topology. Among Spinoza's core metaphysical doctrines is his view that thought and extension are both infinite powers of nature, and everything expresses as much intellectual power as it does corporeal power (Spinoza, 2002: 247, E IIp7). A mind is as free or servile, as powerful or weak, as selfdetermining or other-dependent, as its body (see Montag, 1999: Ch. 2). Spinoza's theory of mind, moreover, extends to all beings, even those most would consider to be inanimate. 'For what we have so far demonstrated [concerning the nature and origin of the mind] is of quite general application, and applies to men no more than to other individual things, which are all animate, albeit to different degrees' (Spinoza, 2002: 251, E IIp13s). The universality of 'animation' or mindedness is such a comprehensive principle that Spinoza analogizes the subjectivity of stones, circles, and triangles to that of human beings. It is not only the case that mountain gorillas, ant colonies, or forests think. All finite things persist in thought and extension to the same extent and, he suggests, with a similar orientation toward the world. In a strange kind of thought experiment, Spinoza insists that, if geometric figures or rocks could convey to us their selfexperience, they would tell us both that they are free and that what is best is whatever most resembles them. Spinoza urges an interlocutor, Hugo Boxel, to imagine a stone or a triangle structured by a similar moral psychology to our own: my kind is free, exceptional, superior, and of superlative value. Spinoza observes that a stone thrust through the air is ignorant of those causes that allowed it to so fly. But its point of view is such that, just like us, it would believe that its flight was brought about by its own endeavor, and that its motion was a consequence of its self-originating desire. 'This, then, is that freedom which all men boast of possessing', Spinoza insists. Our understanding of ourselves as uniquely self-determined is nothing but the perspectival and limited character of knowledge: we typically know only the proximate causes of our desires. Yet, our freedom to execute an action is not different in kind from the freedom of a stone catapulted through the air. In the same letter, Spinoza surmises that:

a triangle, if it could speak, would likewise say that God is eminently triangular, and a circle that God's nature is eminently circular. In this way, each would ascribe to God its own attributes, assuming itself to be like God and all else to be ill-formed. (Spinoza, 2002: 908-910)

Thus, Spinoza suggests that not only do all things exist in thought as much as they do in extension, they all attribute to themselves a unique kind of freedom and value that distinguishes them from all other beings. By comparing humans not to 'higher' animals but to stones and triangles, Spinoza radically reconfigures human metaphysical priority.

Spinoza frequently urges his reader to grasp humanity through the prism of geometry, considering 'human actions and appetites just as if it were an investigation into lines, planes, or bodies' (Spinoza, 2002: 278, E IIIpref). However literally one takes his analogies, it is undeniable that, at the level of metaphysics, Spinoza profoundly disrupts the foundations of humanism, according to which humans are uniquely minded, at least partially exempt from the general laws of nature, and thereby superior. As Ruddick emphasizes, he also disrupts individualist conceptions of 'thinghood' by presenting human modes as, like all modes, ineluctably bound to others, not only dependent on them in order to exist and act but also only ever provisionally distinct from them. As composite individuals operating within a vast causal network, we must integrate others and exchange parts of ourselves in order to continue to exist. Our being constantly overflows our ostensible bodies, just as 
our bodies are comprised of more bacterial cells than human ones (Wenner, 2007). With bounded individuality and human exceptionalism off the table, how do we negotiate the conflicts that anthropogenic ecological devastation render increasingly acute?

Revolutionary perspectives in metaphysics and ontology refuse both the dualism, according to which mind is other than and superior to body, and human exceptionalism, according to which humans are the only free and minded beings. With the negation of these two doctrines, we have an insurrection against the kingdom of ends. Ruddick proposes that the disruption of metaphysical privilege demands new scales of justice, but it is not clear that the revolutionary perspectives in ontology, metaphysics, and epistemology are up to the task. Those who have long worked on bringing justice to a consideration of nonhuman nature, however, typically move the walls surrounding the human kingdom but leave the fortress intact (e.g. Regan, 2004). In my view, we have a situation in which the more radical philosophical outlook all but ignores practical considerations, but the practical approach is overly modest with respect to the metaphysical topography. Influenced by Deleuze, the radical ontologists understandably avoid moral judgments, but it is worth remembering that Deleuze admired Spinoza above all for his practical philosophy (Deleuze, 1988).

Although Spinoza is frequently cited as inspiration for radical perspectives in ontology, he is generally not viewed as a friend to environmental ethics (Houle, 1997; Lloyd, 1980). Spinoza interrupts the foundations of human exceptionalism and species superiority, but he does not advocate balancing human interests with nonhuman beings (Spinoza, 2002: 338, E IVp35s). Just as a triangle would necessarily prefer all things insofar as they are triangular, humans are determined to prefer and value what they deem (correctly or not) to be most human. It belongs to the essence of each and every being to strive to persevere with as much vitality and perfection as is available to it (Spinoza, 2002: 283, E IIIp6). Spinoza takes self-preference and selfpreservation to be both desirable and virtuous (Spinoza, 2002: 330-331, E IVp18s).

Nevertheless, he acknowledges that all finite beings are profoundly vulnerable, persisting within a force field of powers and counterpowers. There are always other beings in nature by which one can be destroyed (Spinoza, 2002: 323, E Ivax1). Even if his ontology is flatter than traditional ones, his practical philosophy is not at all flat. Simply put, and pace the deep ecological interpretation (Sessions, 1977), no ethical prescriptions follow from the fact that everything is natural, minded, and conative. We can all help or hurt one another by virtue of existing within the same system of causal relationships. But our vulnerability to hostile forces does yield a prescriptive ethics of mutually enabling composition. To live, we need to combine with those other beings and forces that amplify and support our existence. Spinoza regarded other humans as unquestionably the most important allies in our effort to maximize our mental and corporeal powers (Spinoza, 2001: 331, E IVp18s). But he also regarded humans as the most dangerous others in nature (Spinoza, 2002: 686). Species membership is not what makes an alliance, or a super composition, enabling. It is a question only of the extent to which another can increase the power of the mind to produce ideas and the body to undergo and generate affects (Spinoza, 2002: 341, E IVp38). The assessment of which encounters enrich and contribute to one's existence and which do not is the sensitive contextual work of practical reason (reason illuminated by imagination). The art of forming more enabling compositions within a causal network is very difficult, since it involves discerning the unanticipatable effects of encounters among singular beings with distinctive needs and variable affective complexions. Spinoza paid little attention to the nonhuman powers that necessarily sustain and amplify a human's life, let alone the adverse effects human actions have on those nonhuman powers. I have argued that his system encourages an appreciation of those myriad and varied forces (Sharp, 2011b). An appreciation, however, does not provide a means of adjudicating conflicts.

It strikes me that Spinoza contributes a great deal to what I've called revolutionary perspectives in ontology, metaphysics, and epistemology. Moreover, as Ruddick suggests, the sensitivity of his philosophy not only to connection and continuity but also to antagonism and vulnerability provides a useful corrective to those ontologies that dethrone the 
human without sufficient consideration of the distinct forms of violence that characterize human life. Yet, I fear we remain with only the faintest of guidelines in terms of how to evaluate the conflicts provoked by anthropogenic ecological devastation. Certainly, human vitality and perseverance in the 21 st century requires a much keener appreciation of the biotic and atmospheric systems that sustain us than Spinoza ever could have imagined. Spinoza warned us not to communicate or ally with beasts, unable to recognize how such interspecies community could be enriching or vitalizing. He hoped to preempt interspecies conflict by denouncing interspecies community of any kind (see Sharp, 2011a). Yet, it is clear that human vitality, especially on the mass collective level that Spinoza identifies as 'reason's' greatest hope (Spinoza, 2002: 331, E IVp18), requires an increasingly expansive understanding of interdependence, cooperation, and struggle. Although humanity's special place in the universe has been challenged on many fronts, our revision of ethics has only just begun. With Ruddick, I agree that, in the face of 21 st-century climate disruption, we cannot live without an ecological ethics. In this endeavor, Spinoza is our friend, a good friend even, but ours is a rather long-distance relationship.

\section{Declaration of Conflicting Interests}

The author(s) declared no potential conflicts of interest with respect to the research, authorship, and/or publication of this article.

\section{Funding}

The author(s) disclosed receipt of the following financial support for the research, authorship, and/or publication of this article: Research for this article was supported by the Social Sciences and Humanities Research Council of Canada.

\section{References}

Balibar E (1989) Spinoza, the anti-Orwell: the fear of the masses. Rethinking Marxism 2(3): 104-139.
Deleuze G (1988) Spinoza, Practical Philosophy. San Francisco: City Lights Books.

Deleuze G (1994) Difference and Repetition. New York: Columbia University Press.

Descartes R (1988) Selected Philosophical Writings. Cambridge: Cambridge University Press.

Houle K (1997) Spinoza and ecology revisited. Environmental Ethics 19(4): 417-431.

Kant I (1970) Political Writings. Cambridge: Cambridge University Press.

Lloyd G (1980) Spinoza's environmental ethics. Inquiry: An Interdisciplinary Journal of Philosophy 23: 293-311.

Macherey P (1992) Avec Spinoza. Paris: Presses Universitaires Françaises.

Montag W (1999) Bodies, Masses, Power: Spinoza and His Contemporaries. London: Verso Books.

Negri A (1991) The Savage Anomaly. The Power of Spinoza's Metaphysics and Politics. Minneapolis: University of Minnesota Press.

Plumwood V (1993) Feminism and the Mastery of Nature. London: Routledge.

Regan T (2004) The Case for Animal Rights. Berkeley: University of California Press.

Ruddick S (2017) Rethinking the subject, reimagining worlds. Dialogues in Human Geography (this issue).

Sessions G (1977) Spinoza and Jeffers on man in nature. Inquiry 20(1-4): 481-528.

Sharp H (2011a) Animal affects: Spinoza and the frontiers of the human. Journal for Critical Animal Studies 9(1/ 2): 48-68.

Sharp H (2011b) Spinoza and the Politics of Renaturalization. Chicago: University of Chicago Press.

Spinoza B (2002) Spinoza. Complete Works (Shirley $\mathrm{S}$, Trans.). Indianapolis, Cambridge: Hackett Publishing Co.

Wenner M (2007) Human bodies carry more bacterial cells than human ones. Scientific American, 30 November. Available at: http://www.scientificameri can.com/article/strange-but-true-humans-carry-morebacterial-cells-than-human-ones/ (accessed 23 June 2015). 